This PDF is a selection from a published volume from the National Bureau of Economic Research

Volume Title: Health Care Issues in the United States and Japan

Volume Author/Editor: David A. Wise and Naohiro Yashiro, editors

Volume Publisher: University of Chicago Press

Volume ISBN: 0-262-90292-7

Volume URL: http://www.nber.org/books/wise06-1

Conference Date: May 1-3, 2003

Publication Date: September 2006

Title: Market Concentration, Efficiency, and Quality in the Japanese Home Help Industry

Author: Yanfei Zhou, Wataru Suzuki

URL: http://www.nber.org/chapters/c7363 


\title{
Market Concentration, Efficiency, and Quality in the Japanese Home Help Industry
}

\author{
Yanfei Zhou and Wataru Suzuki
}

\subsection{Introduction}

Aging is one of the most challenging problems facing contemporary Japanese society. According to the 2000 population census, the elderly (aged sixty-five and over) as a fraction of the population reached 17.4 percent in 2000 . The elderly fraction is projected to accelerate and reach 27.0 percent in 2017, meaning that the elderly will make up more than onequarter of the Japanese population. ${ }^{1}$ Although aging increases the demand for nursing care services, until quite recently the family network played the traditional primary role in providing care for the frail elderly. However, changes in the social structure, such as weakening community ties, nuclearization of the family, and feminization of the workforce, have made the financial and psychological burdens of family-based care for the aged unbearably large.

In response to the expanding elderly population and the increasing demand for social nursing care services, the Public Nursing Insurance Act (Kaigo Hoken Ho) was formally enacted in September 1997. Under this legislation, the Ministry of Health, Labor and Welfare (MHLW) introduced a new public long-term care insurance system in April 2000. This new system aims to respond to society's major concerns about aging and

Yanfei Zhou is a research fellow at The Japan Institute for Labour Policy and Training. Wataru Suzuki is an assistant professor in the Department of Education at Tokyo Gakugei University.

We are grateful to David Wise, David Cutler, Naohiro Yashiro, Reiko Suzuki, Koichi Kawabuchi, Haruko Noguchi, and Chapin White for their helpful comments on our earlier version. We also appreciate Bank of Japan for permitting us to use their microdata.

1. The source is the medium variant projection of the National Institute of Population and Social Security Research (January, 2003). 
to assure citizens that they will receive care, if necessary, and be supported by society as a whole. ${ }^{2}$

According to the MHLW statistics, the supply of care services expanded after implementing the insurance system. ${ }^{3}$ However, the effects of marketoriented reform on service quality and efficiency are unknown. More specifically, we do not know whether introducing competition by expanding the number of providers in an area can simultaneously improve the quality of service and management efficiency.

Due to the lack of microlevel panel data spanning the transition period, this paper will use cross-sectional data to investigate the effect of market concentration on the quality and cost of home help services. ${ }^{4}$ We choose to focus our analysis on home help services because the reforms in this market have been dramatic, and the proportion of for-profit providers ${ }^{5}$ is one of the highest among the at-home nursing care businesses.

The number of home help service providers (henceforth referred to as care providers) per thousand elderly will be employed as an index of market concentration. To evaluate the impact of market-oriented reform on service quality and efficiency, it is important to know whether care providers in unconcentrated (i.e., highly competitive) markets have a higher level of quality and efficiency than those in highly concentrated markets. This information is also helpful for determining the appropriate number and scale of operations of care providers in each district.

No academic studies have been done on the relationship between market concentration and quality of service or management efficiency among home help providers in Japan. ${ }^{6}$ According to the Survey of Nursing Care Management ${ }^{7}$ (Kaigo Jigyo Keei Jita Chosa) 2002 by MHLW, the higher the market competition (or, the fewer users per care facility) the higher the costs per care plan. This suggests that competition among care providers may lead to higher management costs, which is reminiscent of the "medical arms race hypothesis" in hospital industry research. This paper shows that this finding does not hold in the context of the home health industry when we use an appropriate econometric framework to control for the effect of other related factors such as the quality of service.

2. See $A$ be (2003) for a detailed description of the nursing care system.

3. For example, from April 2000 to February 2002, the number of providers registered in WAM-NET doubled, from 9,185 to 18,389 .

4. Home help service is one of the most important categories of at-home nursing care services. See appendix $\mathrm{A}$ for an introduction to the institutional setting of the at-home nursing care business.

5. According to the Survey of Nursing Care Facilities 2000 by the MHLW, 30.3 percent of home help providers were for-profit companies in December 2000.

6. Shimizutani and Suzuki (2002) investigated the impact of ownership and years in operation on cost and quality using a data set similar to ours.

7. According to the survey results, cost per care plan varies with the number of users per facility. The average cost per care plan in facilities with fewer than 20 users was 12,955 yen, while for those in a facility with more than 200 users, it was only 7,606 yen ( 41 percent less). 
The paper proceeds as follows. Section 6.2 provides a theoretical background and reviews previous empirical research on quality and efficiency issues. Section 6.3 describes the survey data used in this study. Section 6.4 develops the econometric method for estimating the quality and cost functions. Section 6.5 presents empirical results. Specifically, after proposing a set of indices to measure the quality of services, it explores the relationship between market concentration and the quality of services. Section 6.5 also evaluates the effect of market concentration on management after adjusting for quality of services and other related factors. Section 6.6 concludes. Appendix A outlines a set of original indices for measuring quality of care services. Appendix B presents a brief description of the institutional setting of the at-home nursing industry in Japan.

\subsection{Previous Research}

Theoretically, market concentration in an otherwise perfectly competitive market is generally understood to weaken competition and to have undesirable effects on service quality and management efficiency. However, it is also frequently argued that consumers do not necessarily benefit from competition among service providers. The medical care industry is one relevant example. It differs from traditional industries in three aspects: insurance coverage (for most services), the prevalence of nonprofit providers, and the agency role of physicians and medical care staff. Consequently, hospitals tend to compete with each other on nonprice aspects. This wasteful competition is colloquially referred to as the "medical arms race" (MAR). ${ }^{8}$ According to the MAR hypothesis, hospitals compete by providing too many high-technology medical services and hiring excess staff. At the same time, unnecessary duplication of services may cause the quality of care to drop as providers fail to take advantage of the scale of learning effect $^{9}$ (Robinson and Luft 1985; Robinson 1988; Hersch 1984; Luft et al. 1986). Zwanziger and Melnick (1988) find evidence consistent with the MAR hypothesis and infer that, as a result, hospitals compete on quality instead of price.

Although most of the nonprice competition literature falls into the preceding categories, there are some exceptions. After taking into consideration local population structure and market structure, the model of Dranove, Shanley, and Simon (1992) casts doubt on claims that hospital mergers increase efficiency by reducing competition. In addition, Shortell and Hughes (1988) employ in-hospital mortality as an index of quality of service and find no significant association between quality of service and

8. For a more comprehensive review, see Dranove and White (1999).

9. "The scale of learning effect" refers to the inverse relationship between an organization's size and the cost of organizational knowledge. Hence, a market with only one supplier maximizes the scale of learning effect. 
market concentration. Kessler and McClellan (1999) even find a negative relationship between heart attack mortality and the Herfindahl index in United States since 1990, suggesting that competition led both to substantially lower costs and to significantly lower rates of adverse outcomes.

Literature on the effect of market concentration on the cost of nursing home care is quite limited. Assuming the presence of endogenous and unobserved quality, Gertler and Waldman (1992) investigate the effect of cost-saving public policies on the quality of nursing homes using the survey data of New York State. They find that the increases in competition are associated with higher levels of both quality and cost, and that a 1 standard deviation reduction in competition will reduce costs by about 20 percent but reduce quality by only 2.5 percent. Nyman (1994), on the contrary, finds that policies designed to control government expenditure by limiting the number of nursing home beds in an area may result in excess demand and discourage effort by nursing homes to improve management efficiency. Because higher prices may cause private patients to exhaust their financial resources and become Medicaid patients sooner than they otherwise would, policies that limited competition may have had indirect costincreasing consequences.

Few empirical studies have examined the effects of Japan's new "deregulation" policies on the quality and cost of home help services. It should be emphasised, however, that even with the new deregulation policies, the prices of home help services are largely fixed in Japan, resulting in a market that is far from perfectly competitive.$^{10}$ Because providers are unable to attract customers with lower prices, competition for customers centers on advertising or kickbacks to administrative organizations, leading to higher cost without commensurate benefits such as improvement of service quality (Nanbu 2000). Thus, in the case of Japan's home help industry, although we expect a positive effect of market competition on service quality, we cannot predict whether market competition will drive up costs. Hence, it is extremely important and worthwhile to examine these phenomena empirically.

\subsection{Data}

The sample is drawn from the Survey of the Environment Surrounding Home Help Providers, conducted by the Bank of Japan and one of the authors (Suzuki) in August 2000. First, 1,200 providers in Kanto district were selected by the method of population weighted stratified random sampling. ${ }^{11}$ Then questionnaires were sent to each of 1,200 selected providers,

10. The prices of nursing care services are set in detail by the MHLW. The standard prices vary with the type of service, time of day, qualifications of the home helper, and municipality.

11. The distribution of samples by prefectures is as follows: Ibaragi: 80; Gunma: 61; Tochii: 62; Chiba: 174; Saitama: 201; Tokyo: 372; and Kanagawa: 250. 
and 445 valid responses were collected (response rate 37.1 percent). Although some providers are running subsidiary businesses such as at-home bathing or day service, the survey gathered information on management costs and outputs relating solely to the home help business.

The 445 providers in the sample are classified by ownership, with the results summarized in table 6.1. The ownership composition in our data is very similar to data obtained from the nationwide provider census, with the one difference being that providers in our sample consist of relatively more for-profit providers and nonprofit providers such as co-ops, agriculture cooperatives, and nonprofit organizations (NPOs). In addition, the share of social welfare associations and medical corporations is somewhat lower in our sample than in the nationwide data.

Table 6.1

Distribution of providers by ownership category

\begin{tabular}{|c|c|c|c|}
\hline \multirow[b]{2}{*}{ Ownership } & \multicolumn{2}{|c|}{ Our survey } & \multirow[b]{2}{*}{$\begin{array}{c}\text { Nationwide } \\
(\%)\end{array}$} \\
\hline & $\begin{array}{c}\text { No. of } \\
\text { observations }\end{array}$ & Percent & \\
\hline \multicolumn{4}{|l|}{ For-profit providers } \\
\hline \multicolumn{4}{|l|}{ Stock corporations and limited } \\
\hline Individuals & 4 & 0.9 & \\
\hline \multicolumn{4}{|l|}{ Public providers } \\
\hline Local public organizations ${ }^{a}$ & 2 & 0.5 & 2.3 \\
\hline Social welfare associations $\mathrm{s}^{\mathrm{b}}$ & 96 & 22.0 & 20.1 \\
\hline \multicolumn{4}{|l|}{ Nonprofit providers } \\
\hline $\begin{array}{l}\text { Social welfare corporations (ex } \\
\text { social welfare associations) }\end{array}$ & 46 & 10.5 & 18.2 \\
\hline Medical corporations $\mathbf{s}^{\mathrm{d}}$ & 20 & 4.6 & 10.0 \\
\hline Civil corporations ${ }^{\mathrm{e}}$ & 16 & 3.7 & 1.9 \\
\hline Other nonprofit organizations & 49 & 11.2 & 7.0 \\
\hline Total & 437 & 100.0 & 100.0 \\
\hline
\end{tabular}

Source: Nationwide data are derived from the census data conducted by Ministry of Health, Labor and Welfare in July 2000.

${ }^{a}$ Local public organizations are corporations run by local governments directly.

'Social welfare associations are a kind of social welfare corporations that are run by local public organizations. Social welfare associations generally have some advantages in achieving agential jobs or underlying subsidies from the local government but they must afford to embrace redundant staffs from local government as an exchange.

"Social welfare corporations, established by individuals or organizations, are permitted to run social welfare business only. Although social welfare corporations can enjoy equipment subsidies from the government and receive certain tax benefits, they are prohibited to make profit or own estates in personal equipment subsidies from the government and receive certain tax benefits, they are prohibited to make profit or own estates in personal name.

${ }^{\mathrm{d}}$ Medical corporations are nonprofit organizations run by hospitals

${ }^{\circ} \mathrm{Civil}$ corporations run public welfare businesses under the supervision of the regulatory authorities. Civil corporations may enjoy certain tax benefits but generally can not receive any subsidies from the government. 
Our data include detailed information for each home help provider on subsidiary businesses, scale of operations, balance sheets, employee composition, length of operation, and operation costs. We construct three measures of the output of home help services: total hours ${ }^{12}$ of physical nursing service, total hours of housework assistance service, and total hours of combination service (including both physical nursing service and housework assistance service). We also construct a systematic index to measure the quality of services of each home help provider. Table 6.2 presents basic descriptive statistics on the variables used in the analysis.

\subsection{Theoretical Models}

In this section, we develop two models, the first model focusing on providers' choice of quality and the second focusing on the costs of production and efficiency. Specifically, let the care demand function be

$$
Y=Y(P, Q, \mathbf{Z})
$$

where $P$ is the price charged, $Q$ is quality, $Z$ is a vector of exogenous variables that shift the demand curve, such as the competitiveness and demographic characteristics of the care provider's local market. The cost function is

$$
C=C(Y, Q, \mathbf{W}),
$$

where $Y$ is the output of a specific care provider, and $\mathbf{W}$ is a vector of exogenous factor input prices faced by the provider. In this analysis, output $Y$ is classified into three categories: hours of physical nursing service $(A)$, hours of housework assistance service $(B)$, and hours of combination service $(C)$. The input vector $\mathbf{W}$ includes labor cost (labor cost/overall employment hours) and administrative $\cos ^{13}$ (administrative cost/overall employment hours).

Hence, care providers choose price and quality to maximize profits $I$

$$
I=P \cdot Y(P, Q, \mathbf{Z})-C(Y, Q, \mathbf{W}) .
$$

The corresponding first-order conditions are

$$
\frac{\partial I}{\partial Q=0} \rightarrow P \cdot \frac{\partial Y}{\partial Q}=\frac{\partial C}{\partial Q} .
$$

We assume that output $Y$ is exogenous ${ }^{14}$ and that prices $P$ are fixed under the Japanese nursing care price system. Therefore, the equations (1),

12. Total hours $=($ number of users per month $) \times$ (visits per user per month) $\times($ hours per visit).

13. Administrative cost includes the cost of renting office space, the cost of water and heating, as well as the maintenance cost of automobiles.

14. Strictly speaking, $Y$ is not exogenous even in the case of Japanese nursing care market. To make the model as simple as possible, we assume $Y$ to be exogenous. 


\begin{tabular}{|c|c|c|c|}
\hline Variables & $\begin{array}{l}\text { Number of } \\
\text { observations }\end{array}$ & Mean & $\begin{array}{l}\text { Standard } \\
\text { deviation }\end{array}$ \\
\hline Total cost (in 10,000 yen) & 399 & $1,034.52$ & $1,952.70$ \\
\hline Wage (= labor cost/overall employment hours, in yen) & 344 & $1,172.04$ & 238.44 \\
\hline $\begin{array}{l}\text { Administrative cost ( }=\text { administrative cost/overall } \\
\text { employment hours, in yen) }\end{array}$ & 386 & $5,468.03$ & $14,177.37$ \\
\hline Total hours of physical nursing service provided & 427 & 192.77 & 304.40 \\
\hline Total hours of housework assistance service provided & 427 & 307.13 & 613.51 \\
\hline Total hours of hybrid services provided & 427 & 273.94 & 576.04 \\
\hline $\begin{array}{l}\text { Predicted service quality in terms of the total score } \\
\text { (Qhat l) }\end{array}$ & 439 & 8.71 & 0.72 \\
\hline $\begin{array}{l}\text { Predicted service quality in terms of the score of the } \\
\text { first principle factor (Qhat2) }\end{array}$ & 439 & 0.01 & 0.41 \\
\hline Length of operation (in years) & 433 & 7.11 & 14.76 \\
\hline Percentage of branch office & 445 & 30.6 & 0.46 \\
\hline Percentage of providers in region 1 & 445 & 37.3 & 0.48 \\
\hline Percentage of providers in region 2 & 445 & 16.4 & 0.37 \\
\hline $\begin{array}{l}\text { Percentage of providers running medical facility } \\
\text { business simultaneously }\end{array}$ & 445 & 2.0 & 0.14 \\
\hline $\begin{array}{l}\text { Percentage of providers running at-home assistance } \\
\text { business simultaneously }\end{array}$ & 445 & 62.9 & 0.48 \\
\hline $\begin{array}{l}\text { Percentage of providers running at-home bathing } \\
\text { business simultaneously }\end{array}$ & 440 & 13.6 & 0.34 \\
\hline $\begin{array}{l}\text { Percentage of providers running day care business } \\
\text { simultaneously }\end{array}$ & 445 & 14.4 & 0.35 \\
\hline $\begin{array}{l}\text { Percentage of providers running sales and lending } \\
\text { business of welfare equipment simultaneously }\end{array}$ & 445 & 7.9 & 0.27 \\
\hline $\begin{array}{l}\text { Percentage of providers running food delivery business } \\
\text { simultaneously }\end{array}$ & 445 & 1.1 & 0.11 \\
\hline $\begin{array}{l}\text { Percentage of providers running short-stay business } \\
\text { simultaneously }\end{array}$ & 445 & 4.7 & 0.21 \\
\hline $\begin{array}{l}\text { Percentage of providers running at home nursing and } \\
\text { rehabilitation business simultaneously }\end{array}$ & 445 & 2.0 & 0.14 \\
\hline Percentage of regular customers & 400 & 836.1 & 2.42 \\
\hline $\begin{array}{l}\text { Percentage of customers secured before the start of } \\
\text { reform }\end{array}$ & 410 & 404.7 & 3.63 \\
\hline $\begin{array}{l}\text { Percentage of customers in need of nursing care } \\
\text { certified as band } 3 \text { or over }\end{array}$ & 419 & 350.1 & 2.16 \\
\hline Percentage of newer providers & 437 & 56.0 & 0.50 \\
\hline Percentage of for-profit providers & 437 & 46.7 & 0.50 \\
\hline Percentage of nonprofit providers & 437 & 40.7 & 0.49 \\
\hline Percentage of public providers & 437 & 10.8 & 0.31 \\
\hline Number of providers per thousand elderly & 439 & 44.8 & 0.22 \\
\hline
\end{tabular}

Note: Minus values of Qhat 2 have been transformed to suit for a $\log$ form. 
(2), and (4) can be solved for the endogenous variable $Q$ in terms of exogenous variables $Y, \mathbf{W}$, and $\mathbf{Z}$ :

$$
Q=Q(Y, \mathbf{W}, \mathbf{Z})
$$

We choose to represent the equilibrium quality function (5) using the following functional form:

$$
Q_{i}=\alpha_{0}+\alpha_{1} L_{i}+\alpha_{2} Y_{i}+Z_{\rho}+u_{i}
$$

where $L_{i}$ is the total labor hours, and $\mathbf{Z}$ is a vector of exogenous variables for each care provider that includes the market competition level and dummy variables for whether the provider is nonprofit, public, new, or a branch office and dummy variables for region. ${ }^{15}$

Turning to the estimation of the cost function, this analysis employs a quality-adjusted translog cost function. By using the translog cost function, we can make inferences about the principal economic effects without imposing restrictive assumptions on elasticities of substitution among inputs or on returns to scale. The empirical counterpart of equation (2) is the following translog cost function:

$$
\text { (7) } \begin{aligned}
\log C= & \alpha_{0}+\alpha_{y} \log Y+\alpha_{q} \log Q+\sum_{i=1}^{n} \alpha_{w i} \log \mathbf{W}_{i}+\frac{1}{2} \beta_{y y}(\log Y)^{2} \\
& +\frac{1}{2} \beta_{q q}(\log Q)^{2}+\frac{1}{2} \sum_{i} \sum_{j} \beta_{i j} \ln \mathbf{W}_{i} \ln \mathbf{W}_{j}+\beta_{y q} \log Y \log Q \\
& +\sum_{i} \beta_{y w} \log Y \log \mathbf{W}_{i}+\sum_{i} \beta_{q w} \log Q \log \mathbf{W}_{i}+\sum_{i} \varepsilon_{i} \log \mathbf{W}_{i} \\
& +\mathbf{Z} \gamma+u
\end{aligned}
$$

Because we are interested in the effect of $\mathbf{Z}$, particularly market concentration, on cost, we employ $\mathbf{Z}$ as a vector of exogenous variables in the cost function as well. To be consistent with economic theory, the cost function should be linearly homogenous in input prices, and the cross-coefficients must be symmetric, which implies the following restrictions on equation (7):

$$
\sum_{i} \alpha_{w i}=1, \quad \sum_{i} \beta_{i j}=\sum_{j} \beta_{j i}=0, \quad \sum_{i} \beta_{y w}=0, \quad \sum_{i} \beta_{q w}=0
$$

Using Shephard's Lemma, the optimal demand for the $i$ th input is obtain by differentiating the cost function with respect to the price of the $i$ th input $\left(\mathbf{W}_{i}\right)$, that is, the price of labor. Letting $s_{i}$ denote the cost share of in-

15. There are three region dummies, defined to reflect details of the public long-term-care payment system. 
put $i$ and differentiating the cost function of equation (3) with respect to $\mathbf{W}_{i}$ yields the following structure of the cost shares:

$$
s_{i}=\alpha_{w i}+\sum_{j} \beta_{i j} \log \mathbf{W}_{j}+\beta_{y w} \log Y+\beta_{q w} \log Q+\varepsilon_{i},
$$

where $j$ denotes the price of inputs other than labor. The cost equation (7) is estimated jointly with the preceding share equation (8) using nonlinear methods subject to the restrictions imposed previously. In particular, $Q$ will be treated as an observed and endogenous variable to emphasize its role as a quality variable. Its predicted value ( $Q$ hat) obtained from the estimation of quality function, will be employed as an explanatory variable in the cost function. ${ }^{16}$

\subsection{Empirical Results}

\subsubsection{Quality Comparisons}

Currently no uniformed criteria exist for determining the quality of nursing services in Japan. For example, it is well known that the cities of Kobe and Yokohama and Hokkaido prefecture have designed their own sets of local quality criteria and used them in assessment activities. The questionnaire we used ${ }^{17}$ includes fourteen indexes that could be measured objectively and precisely. For analytic convenience, we divided these fourteen indexes ${ }^{18}$ into four categories: quality management, service convenience, information service, and the skills of the home help staff.

In the following we compare the average quality of services among care providers in a highly concentrated local market ${ }^{19}$ with their counterparts in a sparsely concentrated local market. It should be noted that the local market concentration is computed as the number of care providers per thousand elderly (age sixty-five or over), the elderly being the potential users of nursing care services in the area. Table 6.3 employs the four subindexes listed in appendix A to compare the mean scores of providers in the two different types of markets. Areas where the number of providers per thousand elderly is less than the median are categorized as highly concentrated (less-competitive) markets.

We prepared two sets of scores to measure the overall quality of care.

16. Gertler and Waldman (1992) treat quality as endogenous, unobservable variable.

17. Shimizutani and Suzuki (2002) have used an even more comprehensive index derived from a survey performed by the Cabinet Office of the Japanese government in 2001.

18. See appendix A for detailed descriptions about the fourteen subindexes.

19. The common assumption of local market is the municipality in which the care provider is located. There are certainly a few users whose care provider is located in a neighboring municipality, but we assume most users in Japan are using facilities inside their residence municipality. 


\begin{tabular}{lcccc}
\hline Subindex of quality of services & $\begin{array}{c}\text { All } \\
\text { providers }\end{array}$ & $\begin{array}{c}\text { Providers in } \\
\text { low-concentrated } \\
\text { market }\end{array}$ & $\begin{array}{c}\text { Providers } \\
\text { in highly } \\
\text { concentrated } \\
\text { market }\end{array}$ & $\begin{array}{c}\text { Relative } \\
\text { score }^{\text {* }}\end{array}$ \\
\hline Quality management & 2.20 & 2.24 & 2.10 & $+*$ \\
Service convenience & 2.84 & 2.89 & 2.74 & + \\
Information service & 1.65 & 1.63 & 1.69 & - \\
Ability of the home help staff & 1.88 & 1.87 & 1.92 & - \\
Total score & 8.69 & 8.77 & 8.55 & + \\
Score of the first principle factor & 0.000 & 0.037 & -0.069 & + \\
\hline
\end{tabular}

Notes: We define markets where the number of care providers are less than the average level as highly concentrated (less-competitive) market, or we define the markets as low-concentrated (more competitive) ones.

"In the last column of each score, "+ "implies that the average score of providers in the low-concentrated market is higher than that in the highly concentrated market, while "-" refers to the reverse.

*Significant at the 10 percent level.

The "total score" is calculated by simply adding the scores for each subindex, and hence each query is equally weighted. The "score of the first principal factor" is estimated by principal factor analysis, where each index was assigned different weights. In table 6.3, a "+" ("-") indicates that the average score of providers in highly competitive (low-concentration) markets is higher (lower) than that of the providers in less-competitive markets.

According to the results in table 6.3, for half of the subindexes the sign on the differences between types of markets supports the hypothesis that care providers in highly competitive markets are providing better services. Comparisons using the total score and the scores of the principal component, which are more comprehensive indices of quality, are in accordance with our expectation. The magnitudes of the quality gaps are quite small, however, and only the quality management subindex differs significantly between providers in high-concentration markets versus lowconcentration markets.

The results in table 6.3 are informative but lack statistical significance and ignore important information because the market concentration variable is treated as a binary variable (above or below average). Furthermore, given that the service quality of care providers could be influenced by other factors besides market concentration, it is important to control for their separate effects using multiple regression.

The quality function in equation (6) is estimated with ordinary least squares (OLS) using a Huber-White Sandwich estimator of the variance, which accounts for heteroscedasticity to some extent. Table 6.4 highlights the estimated coefficients on the market competition ratio (which equals 


\begin{tabular}{lccc}
\hline & \multicolumn{2}{c}{ Competition level ratio } & \\
\cline { 2 - 3 } & Coefficient & t-value & Adjusted $R^{2}$ \\
\hline Case 1: Quality management & -0.131 & -0.58 & 0.173 \\
Case 2: Service convenience & -0.031 & -0.12 & 0.087 \\
Case 3: Information service & $0.273^{* *}$ & 2.37 & 0.088 \\
Case 4: Ability of the home help staff & 0.122 & 1.17 & 0.110 \\
Case 5: Total score & 0.110 & 0.29 & 0.117 \\
Case 6: Score of the first principle factor & 0.097 & 0.56 & 0.180 \\
\hline
\end{tabular}

Notes: Estimations are based on the following equation:

$$
\begin{aligned}
Q= & \beta(0)+\beta(1) \cdot \text { ratio }+\beta(2) \cdot \text { nonprofitdummy }+\beta(3) \cdot \text { publicproviderdummy } \\
& +\beta(4) \cdot \text { newproviderdummy }+\beta(5) \cdot \text { regiondummies }+\beta(6) \cdot \text { branchdummy } \\
& +\beta(7) \cdot \text { laborhours }+u,
\end{aligned}
$$

where $Q$ is the dependent variable that is the score of each subindex (cases 1 to 4 ), or the total scores (case 5), or the principle component scores (case 6), and ratio is the number of care providers per thousand people in the population. This table highlights the estimated parameters of ratio only. The equation in case 1 is estimated by OLS with a Haber-White Sandwich estimator of variance, and hence the heteroskedasticity of residuals is adjusted.

**Significant at the 5 percent level.

the number of care providers per thousand population). The estimation results present a somewhat different image from the descriptive statistics in table 6.3. Contrary to the results in table 6.3, the competition ratio has a positive effect on the third index of service quality, after controlling the effects of other covariates such as ownership dummy and region dummy. In other words, with all else held constant (scale of operations, region, and ownership), home help providers' information services improve as market competition rises. However, the competition ratio has no effect on the other three subindexes or the two comprehensive indexes. In sum, the effect of market concentration on service quality, if one exists, is quite limited.

\subsubsection{Efficiency}

Table 6.5 reports results of the translog cost function analysis, where case 1 employs the sum of total scores as an index of the quality of services, and case 2 employs the score of the first principal component as a proxy for quality of service.

As shown in table 6.5, although there are some differences in the magnitude of coefficients and $t$-values, we find no substantial differences between the parameter estimates across the two cases. For the market concentration variable, which is our focus, both cases 1 and 2 indicate that an increase in competition is associated with lower cost. In other words, the statistically significant negative coefficient on the market concentration index indicates that the number of care providers per thousand elderly is negatively associated with cost. This result is in accordance with that of Nyman (1994), 


\begin{tabular}{|c|c|c|c|c|}
\hline & \multicolumn{2}{|c|}{$\begin{array}{l}\text { Case 1: } \\
\text { Quality }=\text { total score }\end{array}$} & \multicolumn{2}{|c|}{$\begin{array}{c}\text { Case 2: } \\
\text { Quality = first PC }\end{array}$} \\
\hline & Coefficient & $t$-value & Coefficient & $t$-value \\
\hline In (Total hours of physical nursing service) - A & $1.1850^{* *}$ & 2.40 & $0.9120^{* *}$ & 2.51 \\
\hline In (Total hours of physical nursing service)^2 & $0.0076^{* * *}$ & 3.17 & $0.0062^{* * *}$ & 2.69 \\
\hline $\ln$ (Total hours of house work assistance service) - B & 0.6675 & 0.86 & $0.8485^{*}$ & 1.66 \\
\hline $\ln ($ Total hours of house work assistance service)^2 & 0.0015 & 0.61 & 0.0010 & 0.43 \\
\hline $\ln$ (Total hours of hybrid services) - C & -0.0816 & -0.11 & -0.5506 & -1.06 \\
\hline $\ln \left(\right.$ Total hours of hybrid services) ${ }^{\wedge} 2$ & $0.0074^{* * *}$ & 2.97 & $0.0062 * *$ & 2.54 \\
\hline $\ln (\mathrm{A}) \cdot \ln (\mathrm{B})$ & 0.0004 & 0.17 & 0.0017 & 0.72 \\
\hline $\ln (\mathrm{B}) \cdot \ln (\mathrm{C})$ & 0.0036 & 1.54 & $0.0049 * *$ & 2.12 \\
\hline $\ln (\mathrm{C}) \cdot \ln (\mathrm{A})$ & 0.0022 & 0.88 & 0.0031 & 1.30 \\
\hline $\ln$ (Wage) or $\ln (W)$ & $2.2347^{* * *}$ & 3.59 & $1.4320^{* * *}$ & 4.92 \\
\hline $\ln (\text { Wage })^{\wedge} 2$ & -0.0345 & -1.57 & -0.0310 & -1.47 \\
\hline $\ln (\mathrm{Admin}$, cost) or $\ln (\mathrm{AC})$ & $-1.2347^{* *}$ & -1.98 & -0.4320 & -1.49 \\
\hline $\ln (\mathrm{AC})^{\wedge} 2$ & $0.0508^{* * *}$ & 12.58 & $0.0494^{* * *}$ & 12.70 \\
\hline $\ln (\mathrm{W}) \cdot \ln (\mathrm{AC})$ & -0.0164 & -0.70 & -0.0184 & -0.82 \\
\hline $\ln (\mathrm{A}) \cdot \ln (\mathrm{W})$ & -0.0322 & -0.60 & -0.0764 & -1.39 \\
\hline $\ln (B) \cdot \ln (W)$ & 0.0056 & 0.11 & -0.0106 & -0.21 \\
\hline $\ln (\mathrm{C}) \cdot \ln (\mathrm{W})$ & 0.0149 & 0.21 & 0.0682 & 0.95 \\
\hline $\ln (\mathrm{A}) \cdot \ln (\mathrm{AC})$ & 0.0022 & 0.58 & 0.0023 & 0.60 \\
\hline $\ln (\mathrm{B}) \cdot \ln (\mathrm{AC})$ & 0.0051 & 1.61 & $0.0063^{* *}$ & 2.05 \\
\hline $\ln (\mathrm{C}) \cdot \ln (\mathrm{AC})$ & 0.0043 & 0.37 & 0.0103 & 0.96 \\
\hline $\ln$ (Qhat) & $79.5113^{* * *}$ & 4.45 & $46.1283^{* * *}$ & 5.18 \\
\hline $\ln (\text { Qhat })^{\wedge} 2$ & $-12.4044^{* * * *}$ & -3.13 & $-8.4008^{* * *}$ & -2.79 \\
\hline $\ln (\mathrm{Qhat}) \cdot \ln (\mathrm{A})$ & $-0.3935^{*}$ & -1.82 & -0.2020 & -1.27 \\
\hline $\ln (\mathrm{Q}$ hat $) \cdot \ln (\mathrm{B})$ & -0.3095 & -1.14 & $-0.5321^{* * *}$ & -2.84 \\
\hline $\ln (\mathrm{Qhat}) \cdot \ln (\mathrm{C})$ & 0.0294 & 0.11 & 0.1172 & 0.60 \\
\hline $\ln ($ Qhat $) \cdot \ln (\mathrm{W})$ & $-0.9191^{* * *}$ & -3.05 & $-0.8286^{* * *}$ & -4.51 \\
\hline $\ln (\mathrm{Qhat}) \cdot \ln (\mathrm{AC})$ & $0.9191^{* * *}$ & 3.05 & $0.8286^{* * *}$ & 4.51 \\
\hline Length of operation & 0.0016 & 0.50 & 0.0016 & 0.52 \\
\hline Branch office dummy & $-0.7974 * * *$ & -6.36 & $-1.3453^{* * *}$ & -8.81 \\
\hline Dummy for region 1 & $-0.7129^{* * *}$ & -5.71 & $-0.5752^{* * *}$ & -5.06 \\
\hline Dummy for region 2 & $-1.0610^{* * *}$ & -7.21 & $-0.7165^{* * * *}$ & -5.70 \\
\hline Dummy for medical facilities & 0.2362 & 0.79 & 0.1609 & 0.56 \\
\hline Dummy for at-home assistance business & -0.0218 & -0.24 & -0.0048 & -0.05 \\
\hline Dummy for at-home bathing business & -0.0004 & 0.00 & 0.0334 & 0.30 \\
\hline Dummy for day care business & 0.1115 & 0.78 & 0.1815 & 1.30 \\
\hline $\begin{array}{l}\text { Dummy for sales and lending business of welfare } \\
\text { equipments }\end{array}$ & -0.1727 & -1.19 & -0.1826 & -1.31 \\
\hline Dummy for food delivery business & -0.7331 & -1.45 & -0.7025 & -1.44 \\
\hline Dummy for short-stay business & 0.0486 & 0.23 & 0.0099 & 0.05 \\
\hline $\begin{array}{l}\text { Dummy for at home nursing and rehabilitation } \\
\text { business }\end{array}$ & 0.0713 & 0.24 & 0.0181 & 0.06 \\
\hline Proportion of regular users & -0.0089 & -0.47 & -0.0173 & -0.93 \\
\hline Proportion of users secured before 2000 & 0.0092 & 0.57 & 0.0075 & 0.49 \\
\hline $\begin{array}{l}\text { Proportion of users in need of nursing care band } 3 \\
\text { or over }\end{array}$ & 0.0056 & 0.24 & 0.0140 & 0.63 \\
\hline
\end{tabular}




\begin{tabular}{|c|c|c|c|c|}
\hline & \multicolumn{2}{|c|}{$\begin{array}{c}\text { Case 1: } \\
\text { Quality = total score }\end{array}$} & \multicolumn{2}{|c|}{$\begin{array}{c}\text { Case 2: } \\
\text { Quality = first PC }\end{array}$} \\
\hline & Coefficient & $t$-value & Coefficient & $t$-value \\
\hline Dummy for newer provider & $0.4581^{* * *}$ & 3.79 & -0.1088 & -1.01 \\
\hline Dummy for nonprofit provider & $0.6459 * * *$ & 4.62 & $0.7016^{* * *}$ & 5.21 \\
\hline Dummy for public provider & $0.3718^{* *}$ & 2.17 & $1.1954^{* * *}$ & 6.10 \\
\hline Index of market concentration & $-0.2815^{*}$ & -1.65 & $-0.3813^{* *}$ & -2.31 \\
\hline Constant & $-108.1708^{* * *}$ & -5.23 & $-42.0996^{* * *}$ & -6.17 \\
\hline$R^{2}$ & \multicolumn{2}{|c|}{0.7022} & \multicolumn{2}{|l|}{0.7193} \\
\hline Number of observations & \multicolumn{2}{|c|}{306} & \multicolumn{2}{|c|}{306} \\
\hline
\end{tabular}

Notes: The dependent variable is the logarithm of the total expenditure $(\mathrm{ln}[\mathrm{C}])$ of individual provider. Index of market concentration refers to the number of care providers per thousand in each area. First principle factor has been transformed to suit for a log form.

*** Significant at the 1 percent level.

** Significant at the 5 percent level.

*Significant at the 10 percent level.

but as we mentioned in the introductory section, it is contradicted by the descriptive results of MHLW.

The estimation of the cost function has some other interesting implications. First, among the three kinds of home help services, only physical nursing service is significantly associated with higher cost in both cases. This result is consistent with the notion that physical nursing care is the most costly service among the three kinds of home help service. Second, running subsidiary businesses imposes no significant effect on cost. This result is somewhat surprising but suggests a lack of compensatory benefits between home help and other at-home nursing care businesses. Third, branch offices have lower costs than headquarters in both cases, with the possible reason being that the branch office requires lower costs for advertising, information collection, or employee training. Fourth, newer care providers are less cost-efficient than the older care providers (case 1 only), after controlling for ownership effect and quality of services. This result is quite natural because the newer providers require more initial investment cost than the older ones. In addition, coefficients on the nonprofit provider dummy and public provider dummy are positive and significant in both cases. ${ }^{20}$ This outcome is quite plausible because it is well known that nonprofit or public providers generally lack incentives to minimize costs. Finally, the coefficient on quality is positive and statistically significant, which implies that a tradeoff relationship exists between quality and cost.

20. Shimizutani and Suzuki (2002), on the contrary, have reported a significantly negative relationship between public provider dummy and cost. 


\subsection{Concluding Remarks}

Because of the dramatic aging of Japan's population, the nursing care system in Japan has been reformed in order to stimulate the supply of care services and improve quality. This analysis focuses on the home help industry and investigates whether market competition improves quality or reduces costs.

This analysis contributes to Japan's nursing care literature in the following aspects: first, it is the first study to use cross-section data to probe the relationships among market concentration, cost, and quality in an econometric framework. Second, it estimates the cost function while controlling for the effect of quality, an observable and endogenous variable in our model. Hence, our analysis provides statistically reliable results. Third, it develops a set of comprehensive and systematic indices to evaluate the quality of nursing services, which could be a useful reference for government decision-making.

Our major findings are summarized as follows:

1. Holding constant the scale of operations, region, and ownership, we find a positive relationship between market competition and quality of services only in the case of information services. This result shows that the impact of market competition on the quality of care service, if any, was quite limited in 2000 .

2. Contrary to the impression created by the descriptive results from the survey by MHLW, this analysis shows that competition is associated with lower costs. In other words, market competition induces cost savings in the home help care market.

3. We also find that there is a tradeoff between quality and cost, running a subsidiary business has few cost-saving premiums, branch offices have lower costs than headquarters, and new providers and nonprofit providers incur higher costs than their counterparts.

Turning to policy implications, although we hesitate to generalize our findings beyond the home help business, ${ }^{21}$ this paper suggests that there are no foundations for the concern that market-oriented reforms will sacrifice quality in the name of cost savings.

21. Because the amount of competition in different areas may be correlated with unobserved characteristics that in turn affect cost and quality, we need some further tests to determine whether cross-sectional analysis can be interpreted as informative on any causal relationship between competition and cost and quality. 


\section{Appendix A}

Table 6A.1 Measurement of the quality of service

Items in each subindex

\begin{tabular}{|c|c|c|c|c|}
\hline \multirow[b]{2}{*}{ Subindex } & \\
\hline & Item 1 & Item 2 & Item 3 & Item 4 \\
\hline Quality management & $\begin{array}{l}\text { Has your establishment } \\
\text { acquired silver mark or ISO } \\
\text { approval? }\end{array}$ & $\begin{array}{l}\text { Does your establishment } \\
\text { have a standard manual for } \\
\text { home help service? }\end{array}$ & $\begin{array}{l}\text { Does your establishment } \\
\text { regularly hold information } \\
\text { exchange meetings, case } \\
\text { study meetings, or care } \\
\text { conferences? }\end{array}$ & $\begin{array}{l}\text { Does your establishment } \\
\text { provide your own regular } \\
\text { staff training? }\end{array}$ \\
\hline Service convenience & $\begin{array}{l}\text { Is your establishment settling } \\
\text { no lower limits for utilization } \\
\text { hours? }\end{array}$ & $\begin{array}{l}\text { Can your establishment } \\
\text { provide nursing service late } \\
\text { in the early morning or late } \\
\text { at night? }\end{array}$ & $\begin{array}{l}\text { Can your establishment } \\
\text { always meet emergency } \\
\text { needs? }\end{array}$ & $\begin{array}{l}\text { Can your establishment } \\
\text { provide services on } \\
\text { holidays? }\end{array}$ \\
\hline Information service & $\begin{array}{l}\text { Does your establishment } \\
\text { designate staff to process } \\
\text { claims from customers? }\end{array}$ & $\begin{array}{l}\text { Does your establishment } \\
\text { promulgate its service } \\
\text { content through brochures } \\
\text { or home pages on the web? }\end{array}$ & & \\
\hline Ability of home help staff & $\begin{array}{l}\text { Is the proportion of staff with } \\
\text { the qualification of social } \\
\text { welfare counselor, welfare } \\
\text { caretaker, professional phys- } \\
\text { ical therapist (PTCA), or } \\
\text { operational therapist (OT) } \\
\text { higher than the sample } \\
\text { average? }\end{array}$ & $\begin{array}{l}\text { Is the proportion of qualified } \\
\text { staff higher than the sample } \\
\text { average? }\end{array}$ & $\begin{array}{l}\text { Is the proportion of staff } \\
\text { with more than five years' } \\
\text { experience as a home helper } \\
\text { higher than the sample } \\
\text { average? }\end{array}$ & $\begin{array}{l}\text { Is the proportion of staff } \\
\text { with less than one year of } \\
\text { experience as a home helper } \\
\text { lower than the sample } \\
\text { average? }\end{array}$ \\
\hline
\end{tabular}

Note: "Qualified staff" refers to those who hold at least a certified qualification of second band home helper. 


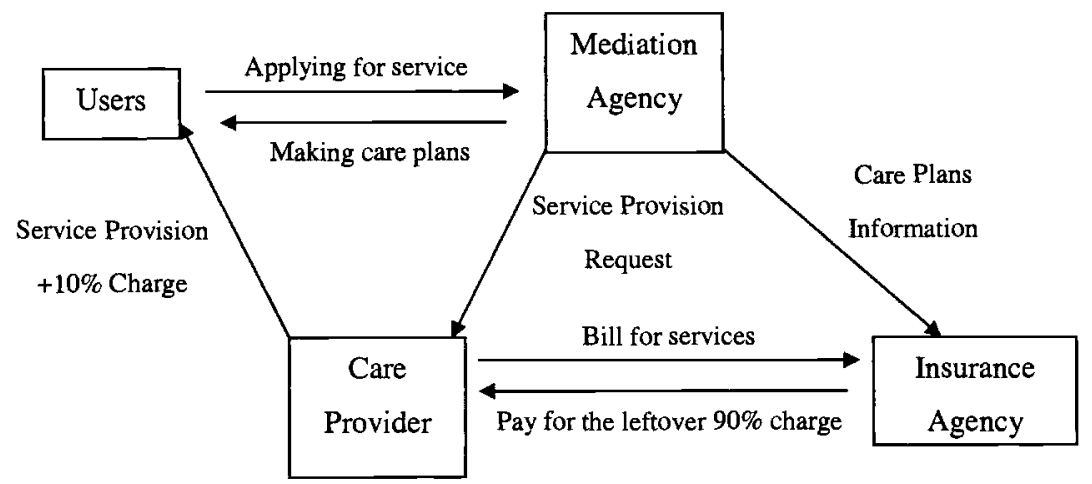

Fig. 6B.1 Flow of money and service provision

Source: Ito $(2001,175)$.

\section{Appendix B}

\section{Institutional Setting of At-Home Nursing Care Business in Japan}

In Japan, at-home nursing care services include a total of thirteen categories: home help service, at-home bathing help, at-home nursing help, at-home rehabilitation help, outpatient rehabilitation help, at-home medical care, management counseling, day-service, short-stay service, group homes for the elderly with dementia, long-term care at private home for the elderly, lending care equipment, and home alteration to meet care needs.

Generally, users afford only 10 percent ${ }^{22}$ of the total cost as long as they do not break the upper limit of use rights, and other expenses are covered by premium incomes ( 50 percent), central government subsidy ( 25 percent), prefecture subsidy (12.5 percent) and municipality subsidy (12.5 percent) ${ }^{23}$ Flow of money and provision of service is summarized in figure 6B.1. In other words, at-home nursing business happens when eligible users apply for service through a mediation agency (care manager). Care providers serve the users based on the care plan made by the care manager and receive payment from both users and insurance agencies.

22. There are upper limits for users' burdens.

23. To improve social welfare, some municipalities have additional subsidy for care providers, which we define as government subsidies in the analysis. 


\section{References}

Abe, A. 2003. Social security in Japan. Tokyo: National Institute of Population and Social Security Research.

Dranove, D., M. Shanley, and C. Simon. 1992. Is hospital competition wasteful? $R A N D$ Journal of Economics 23 (2): 247-62.

Dranove, D., and W. D. White. 1999. How hospitals survived: Competition and the American hospital. Washington, DC: American Enterprise Institute for Public Policy Research.

Gertler, P. J., and D. M. Waldman. 1992. Quality-adjusted cost function and policy evaluation in the nursing home industry. Journal of Political Economy 100 (6): $1232-56$.

Ito, S. 2001. Readdressing nursing care system [in Japanese]. Tokyo: Chikuma Shinsho.

Hersch, P. L. 1984. Competition and the performance of hospital markets. Review of Industrial Organization 1 (4): 324-40.

Kessler, D. P., and M. B. McClellan. 1999. Is hospital competition socially wasteful? NBER Working Paper no. 7266. Cambridge, MA: National Bureau of Economic Research, July.

Luft, H. S., J. C. Robinson, D. Garnick, S. Maerki, and S. McPhee. 1986. The role of specialized clinical services in competition among hospitals. Inquiry 23:83 94 .

Nanbu, T. 2000. Economic consequences of the introduction of public long-term care insurance system into long-term care industry in Japan [in Japanese]. In Analysis of health care and long-term care industry, ed. National Institute of Population and Social Security Research (IPSS), 151-67. Tokyo: Tokyo University Press.

Nyman, A. J. 1994. The effects of market concentration and excess demand on the price for nursing home care. Journal of Industrial Economics 42 (2): 193-204.

Robinson, J. C. 1988. Market structure, employment, and skill mix in the hospital industry. Southern Economic Journal 55 (2): 315-25.

Robinson, J. C., and H. Luft. 1985. The impact of hospital market structure on patient volume, average length of stay, and the cost of care. Journal of Economics 3:1-24.

Shimizutani, S., and W. Suzuki. 2002. The quality and efficiency of at-home longterm care in Japan: Evidence from micro level data. Discussion Paper Series no. 18. Tokyo: Economic and Social Research Institute, Cabinet Office.

Shortell, S. M., and E. F. Hughes. 1988. The effect of regulation, competition and ownership on mortality rates among hospital inpatients. The New England Journal of Medicine 318:1100 07.

Zwanziger, J., and G. Melnick. 1988. The effects of hospital competition and the Medicare PPS program on hospital cost behavior in California. Journal of Health Economics 7:301-20. 
